\title{
VIDA INSUSTENTÁVEL E RECONCILIAÇÃO DA NARRATIVA - ESPAÇO PÚBLICO COMO NATALIDADE METAFÓRICA EM HANNAH ARENDT
}

\author{
UNBEARABLE LIFE AND NARRATIVE'S RECONCILIATION - PUBLIC \\ SPACE AS METAPHORICAL NATALITY IN HANNAH ARENDT
}

By Bethania Assy*

RESUMO: A narrativa de experiências de sofrimentos insuportáveis traz esperança, apresso pelo próprio destino, orgulho por quem fomos, uma espécie de reconciliação com o mundo? Este é exatamente o tipo de expectativa que Hannah Arendt atribui à narrativa. A particular habilidade humana de relembrar e retar tanto suas próprias estórias como a de outros pertence a um dos mais significativos tópicos da inscrição arendtiana sobre narrativa e reconciliação. $\mathrm{O}$ poder redentor da narrativa possui ao menor uma fundamental dimensão abordada por esse artigo: a capacidade de contar a própria estória, narrar quem (who) se é, implica a possibilidade de reconciliação com o próprio passado. A questão mais relevante é que ser narrador de sua própria estória se conecta com a possibilidade de uma reconciliação que não é prívada, mas antes pública, e implica a abilidade de julgar. A reconciliação com nossa própria estória implica reconciliação com o espaço público de aparência, no vocabulário arendtiano, com o mundo plural de fala e ação.

PALAVRAS-CHAVE: narrativa; espaço público; Hannah Arendt; reconciliação; natalidade; julgamento.

\footnotetext{
* Professora assistente do departamento de Direito da Pontifícia Universidade Católica do Rio de Janeiro Puc-Rio e professora adjunta da faculdade de direito da Universidade do Estado do Rio de Janeiro - UERJ. Ph.D. and M.A. em filosofia pela The New School
}

ABSTRACT: How can the narrative of our ungrateful experiences, the facing of unbearable sufferings, bring hopefulness, love for our destines, and pride for who we have been in life, and a sort of reconciliation with the world, reconciliation with the public space of appearance? This is exactly the kind of expectation Arendt assigns for narrative. That we have a particular human ability to recollect, to remember and retell our and others' stories belong to the major topics on Hannah Arendt's writings on narrative and reconciliation. It has at least one crucial dimension this paper will deal with. More closely related to the redemptive power of narrative, we have the potential to be tellers of our own stories, narrators of who we have been in life. Here imagination and recollection help reconciliation towards our own past. By telling our own story, we may become the protagonist of who we are and thereby, as an outcome, we can reconcile ourselves with our life experiences. The main question here is that to be the storyteller of our own story is deeply connected with the possibility of a public reconciliation and our ability to judging. The reconciliation with our story here implies also reconciliation with the public space of appearance, namely by Arendt, the plural world of acting and speech.

KEYWORDS: narrative; public space; Hannah Arendt; reconciliation; natality; judgment.

University - New York, USA. Autora do livro Hannah Arendt - An Ethics of Personal Responsibility. Peter Lang - Frankfurt am Main, Berlin, Bern, Bruxelles, New York, Oxford, Wien, 2008. 
Life is not what one has lived, but rather the life one recollects and how one recollects it to tell. Gabriel García Márquez ${ }^{1}$

'My life, I will not let you go except you bless me, but then I will let you go.' The reward of storytelling is to be able to let go: 'When the storyteller is loyal ... to the story, there, in the end, silence will speak. Where the story has been betrayed, silence is but emptiness. But we, the faithful, when we have spoken our last word, will hear the voice of silence'. Hannah Arendt ${ }^{2}$

Under the guise of introduction, I quote an intriguing question pointed out by Pirro concerning Arendt's approach on narrative, which underlines the main propose of this paper: "why should stories of failed strivings and ruined aspirations foster a sense of hope rather then despair? After all, remembrance of a lost cause seems a slender reed on which to rest one's hopes." ${ }^{\prime 3}$ How can the narrative of our ungrateful experiences, the facing of unbearable sufferings, bring hopefulness, love for our destines and pride for who we have been in life, and a sort of reconciliation with the world, reconciliation with the public space of appearance? This is exactly the kind of expectation Arendt assigns for narrative. By the attempt to relate our fate with the question who we are, Arendt quotes Isak

1 [La vida no es la que uno vivió, sino la que uno recuerda y cómo la recouerda para contarla.] Gabriel García Márquez, Vivir para contarla. Barcelona: Mondadori, 2002, epigraph.

2 ARENDT, Hannah, Men in Dark Times. New York/London: Harvest/HJB Book, 1983, p. 97 (Hereafter quoted as $M D T$ )

3 PIRRO, Robert C., Hannah Arendt and the Politics of Tragedy. De Kalb: Northern Illinois University Press, 2001, p. 21. (Hereafter quoted as Pirro, Hannah Arendt and the Politics of Tragedy).
Dinesen (Karen Blixen), one of her most influential exemplar storyteller figures, who says that ".. in the repetition of imagination the happenings have become what she would call a 'destine.' To be so at one with one's own destiny that no one will be able to tell the dancer from the dance, that the answer to the question, Who are you? Will be the Cardinal's answer, 'Allow me ... to answer you in the classic manner, and to tell you a story,' is the only aspiration worthy of the fact that life has been given us. This is also called pride, and the true dividing line between people is whether they are capable of being 'in love with [their] destine'." "That we have a particular human ability to recollect, to remember and retell our and others' stories belong to the major topics on Hannah Arendt's writings on narrative and reconciliation. It has at least one crucial dimension this paper will deal with. More closely related to the redemptive power of narrative, we have the potential to be tellers of our own stories, narrators of who we have been in life. Here imagination and recollection help reconciliation towards our own past. By telling our own story, we may become the protagonist of who we are and thereby, as an outcome, we can reconcile ourselves with our life experiences. The main question here is that to be the storyteller of our own story is deeply connected with the possibility of a public reconciliation and our ability to judging. The reconciliation with our story here implies also reconciliation with the public space of appearance, namely by Arendt, the plural world of acting and speech.

\footnotetext{
4 Arendt, MDT 105
} 
I. NARRATIVE AND IMAGINATION - A REDEMPTIVE WAY OF THINKING

The intriguing, paradoxical condition of the faculty of thinking allows "the mind to withdraw from the world without ever being able to leave it or transcend it". ${ }^{5}$ It justifies in the first place the use of metaphorical language and imagination, to employ the terms Arendt uses to articulate the imbrications among thinking, judging, narrative, and the visible world. Whether in silent critical thought or in concrete judgment, what is at stake are the outlooks and events of the appearing world transposed into ordinary language. ${ }^{6}$ In the case of thinking activity, it operates through a silent "conceptual metaphorical speech," since thinking "must

5 Arendt, Hannah, The Life of the Mind-Thinking. New York/London: Ed. Harvest/ HJB Book, 1978, p. 45 (Hereafter quoted as $L M T$ ). Taminiaux calls attention to this symmetry: "Not only do most of the words in ordinary language refer to the outlooks and aspects of entities appearing in the world, but even our most abstract way of speaking is full of metaphors which transpose to the activity of the mind words which are originally rooted in appearances. Originally, an idea is an outlook, a concept is a capture, a metaphor is a displacement, a reason is a ground, and son on." Taminiaux, Jacques, "Time and the Inner Conflicts of the Mind," In Hermsen, Joke, \& Villa, Dana, (Eds.) The Judge and the SpectatorHannah Arendt's Political Philosophy. Leuven: Peeters, 1999 , p. 46. It is worth calling attention to the fact that Arendt is not making rigorous conceptual distinctions between any of those terms. See also: Taminiaux, Jacques, "Événement, Monde et Jugement," in Esprit - Changer la culture et la politique, "Hannah Arendt," N. 42, 2 édition, Juin, 1985, pp. 135-47.

6 Arendt would agree with Wittgenstein's argument against a private language: "In all such reflecting activities men move outside the world of appearances and use a language filled with abstract words which of course, had long been part and parcel of everyday speech before they became the special currency of philosophy." Arendt, LMT 78 . prepare the particulars given to the senses in such a way that the mind is able to handle them in their absence; it must, in brief, desense them". ${ }^{7}$ Nevertheless, thinking requires this visibility of being heard and understood by others. "Thought without speech is inconceivable; 'thought and speech anticipate one another. They continually take each other's place "'. ${ }^{8}$ From this sort of conceptual metaphorical speech, it is possible to trace the bridge between thinking and narrative. Narrative derives from human beings' lived experience and therefore must remain tied to it. On the other hand, "what becomes manifest when we speak about psychic experiences is never the experience itself but whatever we think about it when we reflect upon it" ${ }^{\prime \prime}$ Thinking for Arendt has a very particular meaning. Thinking is not equated with the classical attributes of rationality as a cognitive faculty whose criterion is truth and which apprehends concepts through passive perceptions leading to objectively verifiable knowledge. At the same token, imagination is not described in the classical sense, in which it merely (re)-presents images,

\section{ARENDT, LMT 77.}

8 ARENDT, ibid., 32. Quoting Merleau-Ponty. On the more general discussion on mental activity and politics, see: Gray, J. Glenn, "The Winds of Thought," In Social Research. New York, (Spring 1977) Vol. 44: 40-62; Ernst Vollrath, "Hannah Arendt and the Method of Political Thinking." In Social Research, Vol. 44, N. 1 (Spring 1977): 160 - 82; Jean Yarbrough \& Peter Stern, "Vita Activa and Vita Contemplativa: Reflections on Hannah Arendt's Political Thought in The Life of the Mind," in The Review of Politics, vol. 43, N. 3, (July 1981), pp. 323-54; Hans Jonas, “Acting, Knowing, Thinking: Gleanings from Hannah Arendt's Philosophical Work." In Social Research. New York, 44/1 (Spring 1977): 25-43.

9 ARENDT, LMT 31. 
schemas through which intellect and cognition operate. In those classical conceptions of imagination, logic arbitrates meaning; principle precedes prudence and general rules command particular circumstances. In Arendt's understanding, by removing the object, imagination is not merely endowing judgment with the reproductive image to supply the concept, as in the case in determinant logic judgment. ${ }^{10}$ By de-sensing, imagination prepares the objects of thought for reflexive judgment. ${ }^{11}$

${ }^{10}$ Discussed by Kant in the Critique of Pure Reason, in determinant judgment the particular is subsumed under a universally given law, rule or principle. In that case, the play between intellect and imagination is a matter of the pre-given categories of determinant judgment, deontological argumentation, or procedural rationality, where the role of imagination is merely to facilitate understanding - a re-presenting imagination that is basically imitative and reproductive. Abstract and universal schemas are the main outcome of imagination in determinant judgment, an operation of our universal cognitive rationality. On the other hand, reflective judgment rather encompasses a free play of imagination and understanding. In reflexive judgment, rather than intellect providing the rule, imagination provides an exemplary instance. This active perception is able to re-move objects and promote the enlargement of mind. This ethical imagination is the foundation for a subsequent operation, namely reflection, "the actual activity of judging something," which gathers deep political implications. Arendt, Hannah, Lectures on Kant's Political Philosophy. Edited with an interpretative essay by Ronald Beiner. Chicago: The University of Chicago Press, 1982, p. 68.

11 On Arendt's account on reflective judgment see: Dostal, Robert, "Judging Human Action: Arendt's Appropriation of Kant," In The Review of Metaphysics, n. 134, 1984; Forti, Simona, "Sul 'Giudizio Riflettente' Kantiano: Arendt e Lyotard a Confronto.” In La Politica tra Natalità e Mortalita à Hannah Arendt. Edited by Eugenia Parise. Napoli: Edizioni Scientifiche Italiane, 1993; Clarke, James p., "A Kantian Theory of Political Judgment - Arendt and Lyotard." In Philosophy Today, Vol. 38, N. 1/4, (Summer 1994), 135-48; Ferrara, Alessandro, "Judgment, identity and authenticity: a
The important feature here is the link Arendt establishes in language between the world of appearances and the mind's realm of invisibility. "Thinking is the mental activity that actualizes those products of the mind that are inherent in speech and for which language, prior to any special effort, has already found an appropriate though provisional home in the audible world. If speaking and thinking springs from the same source, then the very gift of language could be taken as a kind of proof, or perhaps, rather, as a token, of men's being naturally endowed with an instrument capable of transforming the invisible into an 'appearance." ${ }^{12}$ In this context, metaphor, imagination, terms borrowed from visuality, take the deflated meaning of a "mind's language" and restores thinking to the visible world. This elaborates what can be said through speech: a seeing through "bodily ears." Indeed, metaphor calls for the primacy of the appearing world, but at the same time it attributes narrative an ability to apprehend the visible world apart from the chronological events of everyday life. ${ }^{13}$ Narrative interrupts space and time

reconstruction of Hannah Arendt's interpretation of Kant." In Philosophy \& Social Criticism, 1998, v.242/3, p.110.

\section{ARENDT, LMT 108-9.}

${ }^{13}$ In a longer passage Arendt highlights: "If the language of thinking is essentially metaphorical, it follows that the world of appearances inserts itself into thought quite apart from the needs of our body and the claims of our fellow-men, which will draw us back into it in any case. No matter how close we are while thinking to what is far way and how absent we are from what is close at hand, the thinking ego obviously never leaves the world of appearances altogether. The two-world theory, as I have said, is a metaphysical delusion although by no means an arbitrary or accidental one; it is the most plausible delusion with which the experience of thought is plagued. 
inasmuch as it can make present to the mind a past event through remembrance and anticipate the future by foreseeing an event, in a non-chronological or logical rational way. Such path paved by imagination traces a small track of non-time in which imagination beats within the time-space of mortal men and into which the trains of thought, of remembrances and anticipation run through. ${ }^{14}$ "In terms of tragedy, conceptualizing (through philosophy, analysis, and maxim) cannot be compared with the intensity and richness of significance with a appropriately narrated story." 15

\section{THE MANUFACTURED}

\section{LANGUAGE OF COGNITION - THE HABIT OF REPRODUCTIVE IMAGINATION}

To feel at home in the world embraces the security of habits. The so-called "force of habit" is remarkably described by Augustine in Arendt's Der Liebesbegriff bei Augustin as "a kind of manufactured nature" 16 whose immediate result is to put man at the service

Language, by lending itself to metaphorical usage, enable us to think, that is, to have traffic with non-sensory matters, because it permits a carrying-over, metapherein, of our sense experiences. There are not two worlds because metaphor unites them." Arendt, LMT 110.

14 ARENDT, Hannah, Between Past and Future Eight Exercises in Political Thought. New York: Penguin Books, 1977, p. 13. (Hereafter quoted as BPF) See: Jean-Claude Eslin, "L'Événement de Penser," in Esprit Changer la culture et la politique, "Hannah Arendt," N. 42, 2 édition, Juin, 1985, pp. 7-18.

15 ARENDT, MDT 22.

16 (On Music VI, 19) Arendt, Hannah, Love and Saint Augustine. Edited and with an Interpretive Essay by Joanna Scott and Judith Stark. Chicago/London: The University of Chicago Press, 1996, p. 82 (Hereafter quoted as $L S A$ ). of made objects. Habit is then described as "manufactured"; it is a fabricated form of life, assigning human beings through the work of their hands to the production of the world. Arendt's remarks from her 1929 doctoral thesis anticipate her account of pure cognitive knowledge as the philosophy of the homo faber par excellence in The Human Condition more than 30 years afterwards. ${ }^{17}$

Cognition, which is based on an account of usefulness, embeds a kind of knowledge that, like homo faber's activity, can be approached as "in order to," in terms of utility. It is opposed to "for the sake of," which is understood in terms of meaningfulness. ${ }^{18}$ "Cognition always pursues a definite aim, which can be set by practical considerations as well as by 'idle curiosity'; but once this aim is reached, the cognitive process has come to an end." ${ }^{19}$ Cognition, like fabrication with its instruments and tools, is a process that leads to a proposition. It has a beginning and end and its utility can be demonstrated. Scientific results produced through cognition are added to human artifacts, like material things. Cognitive

17 ARENDT, Hannah, The Human Condition. Chicago/London: The University of Chicago Press, 1989, p. 85 (Hereafter quoted as $H C$ ). Although labor stands for repetition and cyclical, associated with the biological process of living organism, and the process of growth and decay in the world, both leads to an endless self-consuming movement of nature.

${ }^{18}$ In The Human Condition Arendt underscores: "This perplexity, inherent in all consistent utilitarianism, the philosophy of homo faber par excellence, can be diagnosed theoretically as an innate incapacity to understand the distinction between utility and meaningfulness, which we express linguistically by distinguishing between 'in order to' and 'for the sake of."' Arendt, HC 154.

19 ARENDT, ibid. 121. 
processes in science correspond to the function of cognition in fabrication. ${ }^{20}$ Cognition, contributing to the fabrication of our world, is the invisible hand of the manufactured world, producing in us a kind of manufactured nature as well. It leads men to find durability and security in the manmade habitual world, as opposed to the realm of contingency and unpredictability. ${ }^{21}$ Like the realm of homo faber, our fabricated habits provide the durability of the world. This is the sense in which one can say that "habit has already delivered him [man] to the world." 22 Delivering ourselves to the world means the quiet process of composing life through habits. This is a result not only of the instrumentalization of the world, but mostly important here, of the instrumentalization of thinking and judging processes. The pure process of rationalization apprehends language in terms of cognitive logic process, operating under the edge of a reproductive imagination. The manufactured nature of language relies in fact on a reproductive imagination.

${ }^{20}$ In The Human Condition, Arendt distinguishes thinking and from logical reasoning: "In these human faculties we are actually confronted with a sort of brain power which in more than one respect resembles nothing so much as the labor power of the human animal develops in its metabolism with nature" Arendt, HC 172. This type of intelligence, which according to Arendt was mistaken for reason, is a mere substitute for human labor power. It is "a mere function of the life process itself, ... Obviously, this brain power and the compelling logical processes it generates are not capable of erecting a world, are as worldless as the compulsory processes of life, labor, and consumption". ARENDT, ibid. 172.

21 What assures reality is the regular presence of the object detached from us, the habits of cognition that shape passive perception.

22 ARENDT, LSA 82.
Approaching man as toolmaker and fabricator, as the embodied authority of the science of fabrication, as mastering epistémé poétiké, turns the processes of the realm of fabrication into the guarantor of reality. The result is to neglect unexpected experiences, those which fall outside the frame of meansends relationships, making us unable to think and to act not only in unpredictable situations, but also in unbearable experiences. ${ }^{23}$ Besides the encouraging habits, this has two unavoidable outcomes. First, it promotes an over-valorization of a mental and material sense of reality based mainly on mechanization; and second, it thereby promotes what can be called the security of an enduring yesterday. At the same time that habit contributes to the world's enduringness, it creates a false security in reality. As remarkably annunciated by Arendt, already in 1928: "habit is the eternal yesterday and has no future. Its tomorrow is identical with today." 24 In the mechanization of language, the enduring yesterday is the only rain material left to be processed by narrative language. Nevertheless, it is through narrative, and not in cognitive logic process of language in and by itself that a non-time and unpredictable reconciliation with the unbearable is possible.

Diametrically opposed to the security of habit is thaumadzein, the speechless wonder identified with the beginning of the philosophical pathos. It was first equated with

23 See Arendt, HC 300. In terms of political philosophy, it coincides with the creation of the modern political vocabulary, in which, for instance, one speaks of the "fabrication" of "tools" and "instruments" for the creation of the "artificial man" called the State: Hobbes' Leviathan.

24 ARENDT. LSA 83. 
astonishment in the face of the miracle of man, life, and the cosmos as described by Plato in the Theaetetus (155) and Aristotle in the Metaphysics (982b12 ff). In Socratic terms, wonder bears a power to dislodge us from everyday affairs, from "that which is as it is." In order to confront the "dogmatism of mere opinion," Arendt argues, Plato makes this speechless wonder into a way of life (the bios theôrétikos) - philosophy' state of contemplation in which theória has became "only another word for thaumadzein; the contemplation of truth at which the philosopher ultimately arrives is the philosophically purified speechless wonder with which he began." ${ }^{25}$ When converted into theória, however, wonder is reduced to cognition, the mental apparatus of homo faber. To prolong wonder is to crystallize yesterday inasmuch as there is no longer room for perplexity. It is under the aegis of this mental process of fabrication that totalitarianism was able to mechanize the real: through the power of logical reasoning, of cognition, its instruments and tools were able to build a self-explanatory picture of a rather horrifying reality.

Speechless astonishment must remain one moment in the capacity to be ready to join a new pathos of narrative, a necessary estrangement from the everyday life of human affairs. This original wonder was just a fleeting moment “or, to take Plato's own metaphor, the flying spark of fire between

25 ARENDT. HC 302. It is in that sense, as the dimension of contemplative truth, that thaumadzein is opposed to doxadzein, in other words, to a substitution of Greek thaumadzein by the Cartesian doubt. See Arendt, HC 273, 302-304. two flintstones," 26 a spark able to make the enduring yesterday strange. It is this original fleeting moment of strangeness with habitual, given in daily life that incites narrative. Particularly by the "normality, and habituality" of the horror experienced in the catastrophic political events of last half of the Twenty Century, in particular, the Holocaust and its concentration camps, sealed by what Hannah Arendt called "images of Hell on earth." Against the safeness of habit, wonder, perplexity, summons narrative, the act of awareness activated for the sake of meaningfulness. The activity of thinking, the rain material of narrative, holds the same inexorability and recurrence as life itself: it "is as relentless and repetitive as life itself, and the question whether thought has any meaning at all constitutes the same unanswerable riddle as the question for the meaning of life; its processes permeate the whole of human existence so intimately that its beginning and end coincide with the beginning and end of human life itself." ${ }^{27}$

By despatializing the topos of narrative, Arendt emphasizes the human being's capacity of driving and placing the 'past' through remembrance and the future through expectation. By positing memories and prospects, narrative is able to drive temporality. This insertion echoes Augustine's distinction between the principium of the world and the initium of man as well as in his reflections on the notion of time in Confessions. The world of all other living creatures was created "in numbers" and cycles, corresponding to the fabrica Dei. As man expresses his uniqueness

${ }^{26}$ ARENDT, Hannah, "Philosophy and Politics." In Social Research, Vol. 57, N. 1 (Spring 1990), p. 101.

${ }^{27}$ ARENDT, HC 171. 
by initium, by inserting himself into this inbetween present he breaks up the continuum. "Because they are focused on the particle or body that gives them their direction, being fighting with each other and acting upon man is the way Kafka describes." ${ }^{28}$ Time is defined here by the nature of man's activities. In the everyday of animal laborans and homo faber, inasmuch as what takes place is "the continuity of our business and our activities in the world in which we continue what we started yesterday and hope to finish tomorrow, ${ }^{29}$ this continuum determines and conditions time into spatial increments and cyclical time states. It is precisely in such terms that the time of our historical and biographical existence can be "understood in analogy to numerical sequences, fixed by the calendar, according to which the present is today, the past begins yesterday, and the future begins tomorrow." 30 In the Confessions, the philosopher of Hippo coins a remarkable expression to illustrate time, namely, "a present act of attention." This relocates the three time dimensions through the act of attention: the past through memory, the future through expectation, and the present as the act of our attention in both directions. The present therefore cannot be measured in time, since it has no tense between what just happened and what will happen. Rather then three tenses spatially located as a past "behind" and a future "ahead," the present act of attention towards the past through narrative relies on memory. ${ }^{31}$

28 ARENDT, $B P F 11$.

29 ARENDT, LMT 205.

30 ARENDT, Ibid.

31 Augustine, Confessions, Translated by F.J. Sheed, with an introduction by Peter Brown. Indianapolis/

\section{NARRATIVE AND}

CREATIVE IMAGINATION:

A DELIBERATIVE

\section{RECOLLECTING FROM THE} STOREHOUSE OF MEMORY

Recalling Kafka's parable, Arendt mentions so often, one could say that narrative, in being able to displace the appearing world, produces what Arendt calls "diagonal forces" - its "own self-inserting appearance, created by past and future forces, found a place in time which is sufficiently removed from past and future to offer 'the umpire' a position from which to judge the forces fighting with each other with an impartial eye." 32 The non-time element of narrative relies on its reflective ability to locate and to place human beings through their memories and expectations, not only regarding absent objects. Memory holds all the dispositions of recollection and stories. "Only because of the mind's capacity for making present what is absent can we say 'no more' and constitute a past for ourselves, or say 'not yet' and get ready for a future." ${ }^{33}$ Narrative turns us able to constitute a past for ourselves, and prepare us to a future. It means that narrative's attribute of making present what is temporally or spatially absent contains the very condition of judging.

Relying on Augustine's account of memory - what he calls "the fields and vast palaces of memory," ${ }^{34}$ - Arendt distinguishes

Cambridge: Heckett Publishing Company Inc., 1993, (Book Eleven, XX, p. 223) (Hereafter quoted as Augustine, Confessions).

32 ARENDT, BPF 12.

33 ARENDT, LMT 76.

34 As meaningfully put by Augustine: “And so I come to the fields and vast palaces of memory, where 
between two different steps of memory, "what remains in the memory," and "the vision in thought," in order to describe two operations in apprehending the appearing world. " The vision, which was without when the sense was formed by a sensible body, is succeeded by a similar vision within' (Book XI, ch.3) the image that re-presents it. The image is then stored in memory, ready to become a 'vision of thought the moment the mind gets hold of it; it is decisive that "what remains in the memory - the mere image of what once was real - is different from the 'vision in thought' - the deliberately remembered object." ${ }^{35}$ The act of just retaining an image in memory is distinct from the actual act of remembering. Memory's ability to retain an image is different from its ability to impress in the image how and what to remember. ${ }^{36}$ Arendt uses Augustine's terminology to separate the "visible sense-object" from the "image" the memory holds of it, and to distinguish both from the "thought-object," a deliberate act of recollection and remembrance. Hence, all thinking is in fact

are stored the innumerable images of material things brought to it by the senses. Further there is stored in the memory the thoughts we think, by adding to or taking from or otherwise modifying the things that sense has mad contact with, and all other things that have been entrusted to an laid up in memory, save such as forgetfulness has swallowed in its grave." Augustine, Confessions, Book X, VIII, p. 178.

35 ARENDT, LMT 77.

${ }^{36}$ See Arendt, Ibid. (Augustine, Trinity, Book XI, chaps. III, VIII, and, X) "It is because of the twofold transformation of the thinking 'in fact goes even further,' beyond the realm of all possible imagination, 'when our reason proclaims the infinity of number which no vision in the thought of corporeal things has yet grasped' or 'teaches us that even the tiniest bodies ca be divided infinitely.", Arendt, Ibid. a re-thinking, an "after-thought" that requires an "umpire." Thinking is an act of judging under the image requiring a vision-in-thought of the stored image. ${ }^{37}$

By distinguishing the simply apprehension of an image from the active recollection, Arendt underlines the intrinsic link between a reflexive imagination, working through memory's act of recollecting, and narrative. Even though it is through reproductive imagination that the mind stores a image, "these thought-objects come into being only when the mind actively and deliberately remembers, recollects and selects from the storehouse of memory...." 38 This capacity to 'de-sense' a sense-object, which itself never appears to the mind, transforming it into an image, belongs to the imagination. This operation is carried out by what Arendt calls a mere "reproductive imagination," which can be identified with an "elementary ability to de-sense and have present before (and not just in) your mind what is physically absent." 39 On the other hand, it stands a "productive imagination," or creative imagination, which, though dependant upon the reproductive imagination, promotes deliberative selection, a re-location and attribution of meaning to the image. Through

37 "Nor indeed do the things themselves enter: only the images of the things perceived by the senses are there for thought to remember them." Augustine, Confessions, VIII, p. 179 Augustine still calls attention to the fact that since we remember this the memory, we are not disturbed by the emotional qualities of the forth movements (disturbances) of the mind (mens, soul): desire, joy, fear, sadness.
38 ARENDT LMT 77.
${ }^{39}$ ARENDT Ibid., 86. 
the power of imagination man enlarges his capacity to narrate, to come up with a story able to deal with reality. I claim that imagination is one of the key features through which narrative calls for reconciliation with our past and tragic stories. "The world is full of stories, of events and occurrences and strange happenings, which wait only to be told, and the reason why they usually remain untold is, according to Isak Dinesen, lack of imagination - for only if you can image what has happened anyhow, repeat it in imagination, will you see the stories.... Without repeating life in imagination you can never be fully alive, 'lack of imagination' prevents people from 'existing.' 'Be loyal to the story,' ... means no less than, Be loyal to life, don't create fiction but accept what life is giving you, show yourself worthy of whatever it may be by recollecting and pondering over it, thus repeating it in imagination; this is the way to remain alive." "40 Inasmuch as narrative's capacity of creative imagination is an activity, it implies a sort of ethical imagination, since this capacity to transform sense-objects into images involves a capacity of judging.

We have rather become used to limiting the world of sense perception to reproductive imagination. It is fundamental that by creative imagination, Arendt emphasizes that we select not only what to remember but also how to remember. The capacity of fixing on how we produce impressions from within the palaces of memory has a deep impact in the conduct of your own life. The faculty of memory that allows mental enlargement, the

40 ARENDT MDT 97. Emphasis added. Later published as "Foreword" in Isak Dinesen, Daguerreotypes and Other Essays, Chicago: The University of Chicago Press, 1979. expansion of our ethical imagination, is inextricably linked to the ability to judge. Arendt adds the powerful role of narrative to this account, since we face our sorrows literally by how remembering, as much as by sharing our stories with others.

\section{NARRATIVE, JUDGMENT AND RECONCILIATION: A
METAPHORICAL NATALITY}

In the 1964 Chicago manuscript on Kant and judgment, Arendt links appearance, judgment, and reconciliation: "We never are so much members of the sensible world of members of the human society than when we judge of appearance qua appearances. And with respect to communicability as the great source of joy in life, I remain you of Isak Dinesen's: 'All sorrows can be borne if you put them into a story or tell a story about them.' That is, if you communicate. Even grief carries with in an element of joy if it is being told about." ${ }^{41}$ Let me take back the question that introduced this paper pointed out by Pirro concerning Arendt's approach: "why should stories of failed strivings and ruined aspirations foster a sense of hope rather then despair? After all, remembrance of a lost cause seems a slender reed on which to rest one's hopes." 42 The tears of

${ }^{41}$ ARENDT, Hannah, "Kant's Political Philosophy". Seminar, Fall 1964, Chicago University. Unpublished Manuscript. Hannah Arendt's Papers, Manuscript Division, Library of Congress, Washington DC, p. 0322580 .

${ }^{42}$ PIRRO, Hannah Arendt and the Politics of Tragedy, p. 21. On Arendt's account on redemption and narrative see: Benhabib, Seyla "Hannah Arendt and the Redemptive Power of Narrative." In Social Research, Vol. 57, No.1 (Spring 1990), pp.157-96; Hammer, Dean C., "Incommensurable Phrases and 
remembrance bear not only the pure act of bringing the past back through memory, as a closed book to be read. The key element in Arendt's account on the power of narrative relies precisely on the potentiality of some unexpected moments of new beginning, by keeping the meanings of our despair into motion. It holds the possibility of the unpredictable moment of a metaphorical natality, in which reconciliation no longer can be predictable through the regular rational account by a mere accountability of our sufferings. ${ }^{43}$ "The story reveals the meaning of what otherwise would remain an unbearable sequence of sheer happenings." ${ }^{44}$ Here one can subsume that narrative carries an element of unpredictability. The act of narrating brings the capacity to open up a new understanding of the past. Such redemptive

Narrative Discourse - Lyotard and Arendt on the Possibility of Politics." In Philosophy Today, Vol. 41, N. 4/4, (Winter 1997), pp. 475-90.

43 Even though out of the scope of this paper, it is noteworthy to mention that Arendt's account of narrative echoes our capacity to forgive. There can be slender doubt that reconciliation is at least on the way to forgiveness. Narrative's power of redemption is deeply imbricated with the power to forgive. "The possible redemption from the predicament of irreversibility - of being unable to undo what one has done though one did not, and could not, have known what he was doing - is the faculty of forgiving." Arendt, $H C$ 237. Forgiveness depends on plurality and communication, since it "rests on the experiences which nobody could ever have with himself, which on the contrary, are entirely based on the presence of others." Arendt HC 238. It would remain without reality if occurred in solitude or isolation. In the act of forgiving others, the use of imagination is extended, carrying an ethical redemptive dimension. Forgiveness is not merely an appendix of contingence; it is rather a sort of actuality, a potentiality. It is not a mere side effect of our actions. See: Pirro, Hannah Arendt and the Politics of Tragedy.

${ }^{44}$ ARENDT, MDT 104 appeal of the storytelling through remembrance moves precisely among concreteness, particularity, and contingency of human affairs. If, by one hand, it is a way of dealing with real life, rather then a simple psychological internal dimension of the mind to self justify excuses or resentments. On the other hand, narrative can operate imagination as a capacity for "entirely free thinking, which employs neither history nor coercive logic as crutches." 45

Through the abilities of thinking and judging, narrative reaches a dimension far beyond language reduced to cognition, the mental apparatus of homo faber's fabrication, as it has been approached before. Narrative achieves a level beyond the over-valorization of a mental and material sense of reality based mainly on mechanization. Narrative, unlike the power of logical reasoning and cognition, does not mechanize the real. Through its instruments and tools, logical reasoning is able only to build a self-explanatory picture of reality. "The spoken word and all the actions and deeds which the Greeks called prákseis or prágmata, as distinguished from poíesis, fabrication, can never outlast the moment of their realization, would never leave any trace without the help of remembrance." ${ }^{46}$ Narrative rather accomplishes a magnitude beyond the mere rational information. This latter pretends to master the events "once and for all". ${ }^{47}$ It is by

45 ARENDT, Ibid. 8.

46 ARENDT, BPF 44. Arendt adds: "They do this by translating prákseis and léksis, action and speech, into that kind of poíesis or fabrication which eventually becomes the written word" Arendt, ibid., 45.

47 ARENDT MDT 21. As Bilsky accurately calls attention for, Benjamin captures this dimension of 
no means a matter of mastering the past. It rather remains open to interpretation and retelling and thus "can set in motion a process of narration in which a plurality of voices and perspectives is visited." 48 By keeping the meaning of the events alive, narrative illuminates a dimension of suffering, horror, senselessness, which goes far beyond the limits of mere rationalized explanations.

To remember and to narrate our stories implicate to give life, to bring back, those implicated and those circumstances. In a word, it is to revive the scene. At the first sign, it may give the false impression it means merely to bear in mind our misfortune' stories, mostly in a spectral form, as if the main achievement of remembering would be to stay deeply imbedded in the sorrows of our disgraceful experiences. Quite on the contrary, evoked by our capacity to recollect, repeating in imagination the happenings of our life, the capacity to remember opens a powerful dimension: the possibility of freeing us from excuses and resentments. Recalling Dinesen's capacity for recollection, Arendt describes this quality of narrative as a sort of life elixir:

narrative in his essay on storytelling: "It is half the 'art' of storytelling to keep a story from explanation as one reproduces it. ... The most extraordinary things, marvelous things, are related with the greatest accuracy, but the psychological connection of the events is not forced on the reader. It is left up to him to interpret things the way he understands them, and thus the narrative achieves an amplitude that information lacks." Walter Benjamin, Illumination, ed Hannah Arendt, trans. Harry Zohn, (New York, 1969) p. 89. Bilsky, Leora Y., "When Actor and Spectator Meet in the Courtroom: Reflections on Hannah Arendt's Concept of Judgment.” In Beiner, R. \& Nedelsky, J.,(eds.) Judgment, Imagination, and Politics - Themes from Kant and Arendt. New York: Rowman \& Littlefiled Publishers, INC., 2001, p. 272

$$
{ }^{48} \text { BILSKY, Ibid. }
$$

"Recollection, the repetition in imagination, may decipher the essence and deliver to you the 'elixir'; and eventually you may even be privileged to 'make' something out of it, 'to compound the story.' But life itself is neither essence nor elixir, and if you treat it as such it will only play its tricks on you." ${ }^{49}$ Here Arendt's approach on reconciliation through narrative carries neither a sophisticated way of making up reality (the power of "reinventing" reality) nor an emerging language of victimization.

Arendt ultimately ascribes a communal and pluralistic dimension to narrative. The question of company is also deeply involved in remembering. Narrative depends on an "in between." ${ }^{50}$ In the terms of The Human Condition, Arendt's "subjective in-between" space is linked to narrative's ability to

\section{ARENDT, MDT 109.}

50 The spatiality of man-made worldly objects guarantees the durability and relative permanence of the world. This attribute of spatiality in the manufactured world creates a sort of space of maneuver, a shared, inbetween space. According to Arendt, the durability of what is created assures the reality of the world. The reality of life presupposes the eternal recurrence of natality. The birth of man also presumes the durability and stability of the world. Such a continuous and objective man-made world provides an objective space of reality (an objective in-between), the world of objects, the domain of fabrication, the poi sis of the world properly speaking, and a subjective space of reality (a subjective in-between), the common otherness of language and action, the sphere of praxis and interaction that is responsible for establishing a sort of imaginary of the public thing. It is worth underlining that narrative plays a crucial role in guaranteeing this in-between subjective reality, and also grounds the possibility of judging, which is the outcome of a common world. It is in this sense that the plurality and otherness of narrative presuppose the subjective in-between space, the web of relationships among acting and speaking agents Arendt described in The Human Condition. 
constitute an in-between present. Narrative requires a location, which is found in the gap between the past and future. The present act of attention, whose invisible activity implies taking a position, in turn, depends on a search for meaning. "To assume the position of 'umpire,' of arbiter and judge over the manifold, never-ending affairs of human existence in the world, never arriving at a final solution to their riddles but ready with ever-new answers to the question of what it mat be all about." ${ }^{51}$

This positioning has a twofold meaning. Firstly, Narrative's ability to place itself in time occurs through the measure of a beginning and an end of what the mind brings into presence. This stands for man's capacity to establish a present for himself..$^{52}$ Secondly, by attributing to narrative a capacity for breaking with the linear trilogy of time, we have another way of describing the dismantling of the metaphysical tradition.

${ }^{51}$ ARENDT, LMT 210. See: Benhabib, Seyla, "Judgment and The Moral Foundations of Politics in Arendt's Thought." In Political Theory 16/1 (February 1988) pp. 29-51; Collin, Françoise, "Birth as Praxis," in "The Judge and the Spectator - Hannah Arendt's Political Philosophy, Joke j. Hermsen \& Dana R. Villa (Eds.) Leuven: Peeters, 1999, pp. 97-110.

52 In The Life of the Mind, Willing's volume, Arendt emphasizes: "Time that can be measured is in the mind itself; namely, 'from the time I began to see until I cease to see.' For 'we measure in fact the interval from some beginning up to some kind of end,' and this is possible only because the mind retains in its own present the expectation of that which is not yet, which it then "pays attention to and remembers when it passes through" Arendt, Hannah, The Life of the Mind - Willing. New York/London: Ed. Harvest/HJB Book, 1978, p.107. See: Birulés, F., "Poetica e politica. Hannah Arendt, Abitare il present," in La Politica tra Natalità e Mortalita Hannah Arendt. Edited by Eugenia Parise (Napoli: Edizioni Scientifiche Italiane, 1993), pp. 45-62.
It annihilates neither the necessary past nor the unpredictable future. Instead, it orients man in each new situation toward the responsibility to relocate himself, which, like all active experience, only takes place through judging the particular events. ${ }^{53}$

The question of company in which we share our stories also relates to that of judgment, since it concerns one of the concrete and particular domains in which we become spectators of our own life: when our words and deeds are told to others. In a way, through the ability to judge, narrative carries the capacity to conjugate the thinking ego and the ego that appears and moves through the world. ${ }^{54}$ There is an ethical redemptive and cathartic dimension here, in which the other plays a meaningful part. We can put our sorrows into a story in which the lead of narrative does not function in a merely logic descriptive way. "The scene where Ulysses listens to the story of his own life is paradigmatic for both history and poetry; the 'reconciliation with reality,' the catharsis, which, according to Aristotle, was the essence

${ }^{53}$ See: Arendt, Hannah, Responsibility and Judgment. Edited and with an introduction by Jerome Kohn. New York: Schocken Books, 2003. See also: Assy, Bethania, Hannah Arendt - An Ethics of Personal Responsibility. Peter Lang - Frankfurt am Main, Berlin, Bern, Bruxelles, New York, Oxford, Wien, 2008; Bernauer, James, Explorations in the Faith and Thought of Hannah Arendt. Edited by James W. Bernauer, Boston/Dordrecht/ Lancaster: Martinus Nijhoff Publishers, 1987.

${ }^{54}$ Kristeva accurately observes the poetic language of a narrator. See Kristeva, Julia, Hannah Arendt - Life Is a Narrative. Translated by Frank Collins, Toronto/ Buffalo/London: University of Toronto Press, 2001, p. 40 (Hereafter quoted as Kristeva, Hannah Arendt - Life Is a Narrative) 
of tragedy, ... came about through the tears of remembrance." ${ }^{55}$

\section{NARRATIVE: THE LIFE OF A WHO - A MATTER OF WORLD'S RECONCILIATION}

Being the protagonist of our own story does not imply changing our social identity; as if tricking destiny meant merely changing those attributes that constitute what we are, putting in Arendt's vocabulary at the Human Condition, namely, our qualities, gifts, talents, which we can display or hide. ${ }^{56}$ On the contrary, that which is distinctly us, what makes us unique human beings, is the constant ability of each of us, through act and speech, to dimension reality without erases the past, named by Arendt, who we are. "The narrative structure of action and of human identity means that the continuing retelling of the past, its continued reintegration into the story of the present, its reevaluation,

\section{ARENDT, $B P F 45$.}

${ }^{56}$ In The Human condition, Arendt makes a clear distinction between who and what we are. "In acting and speaking, men show who they are, reveal actively their unique personal identities and this make their appearance in the human world, while their physical identities appears without any activity of their own on the unique shape of the body and sound of the voice. This disclosure of 'who' in contradiction to 'what' somebody is - his qualities, gifts, talents, and shortcomings, which he may display or hide - is implicit in everything somebody says and does." Arendt, HC 179. Who someone is, his specific personal identity, akin to his personality, is not identified with his gifts, abilities, and talents. It is through the continuous actualization of personality, the constant exercise of thinking, that we are able to reaffirm our doxai, the formulation in speech of what dokei moi, what appears to me. This formulation in speech discloses who I am, a who that can only emerge in the phenomenal space of appearance. reassessment, and reconfiguration are ontological conditions of the kinds of beings we are" ${ }^{57}$ It is who we are that is responsible for the narrative structure of our identities. Acceptance here has no passive connotation. One accepts reality as provisional, since the who consists in the activity of reiterating oneself in each new, concrete and particular situation. This can involve an ethical leap, a leap into the deep understanding of the sorrowful features by being exposed to the world of appearance. ${ }^{58}$

Narrative is related with the life that can be told as a story, "it is of this life, bios as distinguished from mere zoé, that Aristotle said that it "somehow is a kind of praxis." ${ }_{59}$ This very possibility of narrating grounds human life in what is specific human, not merely as zoé, animal and physiological. ${ }^{60}$ As such, life is not a value in itself, it has his meaning reinvented, over and over again. Suffering can be unbearable, senseless, but it also gathers no significance in itself, it necessarily implies meaning. ${ }^{61}$

57 ARENDT, Hannah, "Philosophy and Politics," Social Research, Vol. 57, No. 1 (Spring 1990), p.98.

58 See the outstanding work of Agamben on the notions klésis-Beruf. Agamben, The Time That Remains. A Commentary on the Letter to the Romans. Translated by Patricia Dailey. Stanford: Stanford University Press, 2005 [Il tempo che resta. Un commento alla Lettera ai Romani, Bollati Boringhieri, 2000]

\section{ARENDT, HC 97}

${ }^{60}$ See Kristeva, Hannah Arendt: Life Is a Narrative.

61 A good parallel can be drawn with the issue of equality as a narrative as well. It is open to discussion in the public domain and is a matter of neither rational nor factual truth. It is a matter of opinion, and human equality depends upon such choices. As beautifully put by Lefort: "Inequality and invisibility go hand in hand. This in itself is enough to suggest that, for Arendt, 
Arendt argues that what the Romans called Humanitas, a unique and vital identity, can only be achieved by throwing oneself into the so-called "adventure of the public realm." 62 The uniqueness of our identity embraces unavoidable the capacity to take and to overcome the risk. Humanitas embodies precisely the courage to be exposed to the unpredictability of life. By that reason, a leap into our own life is an ethical leap; the courage to submit ourselves to life, and the narrative's power of attributing meaning to it. Humanitas is described as something occupying or appearing in a metal space. Narrative is one of the keys to access such mental space. The act of narrating carries the capacity for achieving Humanitas. It means neither a matter of "changing the way events were" in order to make the story bearable, nor just a mere process of rationalizing suffering. The miracle of narrative carries a sort of potentiality of changing the past without changing the past, holding the unpredictable moment of reconciliation.

This reconciliation with our destinies recalls Heller's interpretation of Nietzsche's eternal recurrence in her Ethics of Personality. "The first feature is gratitude towards one's own life inherent in amor fati, a prominent characteristic of an ethics of personality. A person who conduct his life in the spirit of an

equality is an invention; it is an effect or simply a sign of the moment which raises men above life and opens them up to a common world." Claude Lefort, "Hannah Arendt and the Political," in Democracy and Political Theory, University of Minnesota Press: Minneapolis, 1989, p. 51.

${ }^{62}$ It is noteworthy to recall Jaspers' conduct into public life. See Arendt, "Karl Jaspers: A Laudation," in Arendt MDT 73-74. See also: Pirro, Hannah Arendt and the Politics of Tragedy, p. 122 ethics of personality will always say 'yes' to his own life, irrespective of his suffering, his solitude, his marginalization, or his bad luck in all matters that are external to his personality. A 'lucky throw of the dice' says 'yes' to his own life (and thus to life in general). Not because he is lucky in life, but because it is his life, his fate, because he became what he has (always) been. Here we arrive at the deepest layer of Nietzsche's vision of the eternal recurrence of the same. To accept the mythological image of the eternal recurrence of the same with gratitude and gaiety is tantamount to wishing to live one's own life again and again, and never another life, never in another place or in another time. ${ }^{\circ 63}$ Nietzsche points out in Ecce Homo that while writing Zarathustra he was filled by "the Yes-saying pathos par excellence": "the tragic pathos, was alive in me to the highest degree." ${ }^{64}$ Saying "Yes" to life is the tragic pathos of choosing ourselves.

It is not by chance that by making natality the core of her philosophy, Arendt privileges the unpredictability of life over the anticipatory future of being-for-death. This gratitude for life is passed down through memory. Natality, for its part, privileges memory ${ }^{65}$ by bringing out our capacity to judge our irreversible past injuries and mistakes as spectators. Positively

${ }^{63}$ HELLER, Agnes, An Ethics of Personality, Oxford \& Cambridge: Blackwell, 1996, p. 17.

${ }^{64}$ Friedrich Nietzsche, Ecce Homo, 'Thus spoke Zarathustra,' p. 296, In On the Genealogy of Morals, Ecce Homo. Translated by Walter Kaufmann, New York: Vintage Books, 1989.

${ }^{65}$ See the beautiful essay by Antonella Bullo, "Natalità, Mortalità e Memoria," In Hannah Arendt, introduzione e cura di Simona Forti, Millano: Bruno Mondadori, 1999, p.194. 
valuing narrative by not means assigns for attributing to speech and acts the same apparatus as inner rational truth, transposed to the realm of visibility. In giving a metaphorical sense of natality to narrative, by making our suffering bearable, Arendt seeks to reestablish the dignity of who we are into the public sphere, as the realm of an ethics that can make sharing life in society worthwhile. In other words, reconciliation promoted through narrative can only appear where a public space exists. That is the deeper significance of the public realm in the acting of narrating our stories to the others. Thus, perishable individual qualities and talents constant displayed by what we are is not the rain material of narrative. It gathers no ethical meaning into the public realm. Only the ongoing activity of reconciling ourselves with what we went through has a revelatory character of who we are, giving us a deep sense of Humanität. ${ }^{66}$

A singular personal identity can only appear in the form of acts and speech in the

${ }^{66}$ Arendt's concern to describe who someone is never falls into the vocabulary of what someone is. "The manifestation of who the speaker and doer unexchangeably is, though it is plainly visible, retains a curious intangibility that confounds all efforts toward unequivocal verbal expression. The moment we want to say who somebody is, our very vocabulary leads us astray into saying what he is; we get entangled in an description of qualities he necessarily shares with others like him; we being to describe a type or a 'character' in the old meaning of the word, with the result that he specific uniqueness escapes us." Arendt, HC 181. She continues: "the well-known philosophic impossibility to arrive at a definition of man, all definitions being determinations or interpretations of what man is, of qualities, therefore, which he could possibly share with other living beings, whereas his specific difference would be found in a determination of what kind of a 'who' he is." Arendt, Ibid. space between men. Silence and passivity, extra-worldly refuges of interiority, are antagonistic to discourse and action, this latter only takes places where who we are can become known and brought into the luminous world, and consequently, reconciled with the senseless unbearable suffering one experienced. Narrative gathers then reconciliation with, and the new beginning for, our sense of trust in the world. It also can restore the courage of each free man to throw himself again into the unpredictability and irreversibility of action. Courage consists here in throwing oneself into in the plurality of the common world; an act of freedom that ethically dignifies him into the public space of appearance. ${ }^{67}$

The revelatory role of the storyteller relies also on his ability to make some truths more supportable. One of its most radical examples concerns the astonishing power of Holocaust survivors' testimony, which brings forth facts that would otherwise never reach the brightness of the public domain. They are the only ones who can convey the unimaginable reality of the concentration camps, and of the "Muselmänner" Agamben situates at the threshold between man and non-man. Without testimonies, the atrocities would remain "un-truth." ${ }_{68}$ This is not just a matter

${ }^{67}$ See: Étienne Tassin, Le Trésor Perdu, - Hannah Arendt, L'Intelligence de L'Action Politique. Paris: Éditions Payot \& Rivages, 1999. p. 342; Giusti, Roberto, Antropologia della Libertà - A comunità delle singolarità in Hannah Arendt, Assisi: Cittadella Editrice, 1999.

${ }^{68}$ See: Giorgio Agamben, Lo Que Queda de Auschwitz - El Arquivo y el Testigo Homo Sacer III. Traducción de Antonio Gimeno Cuspinera. Valencia: Pre-textos, 2000. See also: Diner, Dan, "On the Banal and the Evil in Her Holocaust Narrative." In New German Critique, N. 71, (Spring-Summer 1997): 177-190. 
of "telling the truth," but of revealing an insupportable reality. Yet by telling a story, testimony not only gives it reality, it can make the reality less unbearable. It is not narrative itself, in the sense of some kind of understanding, rationalism, or analysis that Arendt attributes the capacity to think horror. On the other hand, it is neither irrationalism. It is rather an extended thinking of narrative, able to reach beyond the limits of rationalizing reason. That is the reason why narrative is in tension between bio theórétikos and zoé. Narrative can assign neither for the rationalizing cognitive process due to the professional philosophers, nor for the mere vital process of the animal, physiological life, the so called bare life by Agamben.

Narrative, as an activity in itself, contributes in another life, in our life as bios politicos, since it necessarily requests shared meaning and judgment, the essence of political life for Arendt. "Narrative participates in another politics, that of open memory, renewed and shared memory that she [Arendt] calls the life of a who." ${ }^{69}$ Shared memory is a matter of the public world, since it leaves "the structural potentialities of narration as wide-open and infinite political action, offered to the judging perspicacity of interesse." ${ }^{.70}$ It is an open path to reconciliation

${ }^{69}$ KRISTEVA, Hannah Arendt: Life Is a Narrative, p. 43 .

${ }^{70}$ KRISTEVA, Ibid. Regarding Arendt's approach on judging and politics, see: Denneny, Michael, "The Privilege of Ourselves: Hannah Arendt on Judgment." In Hannah Arendt: The Recovery of the Public World, edited by Melvyn A. Hill, New York: St. Martin's Press, 1979, McClure, Kirstie, "The Odor of judgment: Exemplarity, Propriety, and Politics in the Company of Hannah Arendt." In Hannah Arendt and the Meaning of with our trust in the plural world of appearance. Narrative remains this tremendous human potentiality of new beginning, a sort of miracle keeping into motion the possibility of the unpredictable moment of a metaphorical natality in face of the unbearable life.

\section{REFERÊNCIAS}

AGAMBEN, Giorgio, Lo Que Queda de Auschwitz - El Arquivo y el Testigo Homo Sacer III. Traducción de Antonio Gimeno Cuspinera. Valencia: Pre-textos, 2000.

AGAMBEN, Giorgio. The Time That Remains. A Commentary on the Letter to the Romans. Translated by Patricia Dailey. Stanford: Stanford University Press, 2005 [Il tempo che resta. Un commento alla Lettera ai Romani, Bollati Boringhieri, 2000].

ARENDT, Hannah, "Kant's Political Philosophy”. Seminar, Fall 1964, Chicago University. Unpublished Manuscript. Hannah Arendt's Papers, Manuscript Division, Library of Congress, Washington DC, p. 0322580.

ARENDT, Hannah, "Philosophy and Politics," Social Research, Vol. 57, N. 1 (Spring 1990), p.98.

ARENDT, Hannah, "Philosophy and Politics." In Social Research, Vol. 57, N. 1 (Spring 1990), p. 101.

ARENDT, Hannah, Between Past and FutureEight Exercises in Political Thought. New York: Penguin Books, 1977.

ARENDT, Hannah, Lectures on Kant's Political Philosophy. Edited with an interpretative essay by Ronald Beiner. Chicago: The University of Chicago Press, 1982.

Politics. Edited by Calhoun, Craig \& McGowan, John, Minneapolis e London: University of Minneapolis Press, 1997, pp. 53-84; Barnouw, Dagmar, "The Quality of Judgment: Arendt and Kant." In Visible Spaces: Hannah Arendt and the German-Jewish Experience. London: The John Hopkins Press, 1990. 
ARENDT, Hannah, Love and Saint Augustine.

Edited and with an Interpretive Essay by Joanna Scott and Judith Stark. Chicago/London: The University of Chicago Press, 1996.

ARENDT, Hannah, Men in Dark Times. New York/London: Harvest/HJB Book, 1983.

ARENDT, Hannah, Responsibility and Judgment. Edited and with an introduction by Jerome Kohn. New York: Schocken Books, 2003.

ARENDT, Hannah, The Human Condition. Chicago/London: The University of Chicago Press, 1989.

ARENDT, Hannah, The Life of the MindWilling. New York/London: Ed. Harvest/HJB Book, 1978.

ASSY, Bethania, Hannah Arendt - An Ethics of Personal Responsibility. Peter Lang - Frankfurt am Main, Berlin, Bern, Bruxelles, New York, Oxford, Wien, 2008.

AUGUSTINE, Confessions, Translated by F.J. Sheed, with an introduction by Peter Brown. Indianapolis/ Cambridge: Heckett Publishing Company Inc., 1993.

BARNOUW, Dagmar, "The Quality of Judgment: Arendt and Kant.” In Visible Spaces: Hannah Arendt and the German-Jewish Experience. London: The John Hopkins Press, 1990.

BENHABIB, Seyla "Hannah Arendt and the Redemptive Power of Narrative." In Social Research, Vol. 57, N.1 (Spring 1990), pp.157-96.

BENHABIB, Seyla, "Judgment and The Moral Foundations of Politics in Arendt's Thought." In Political Theory 16/1 (February 1988) pp. 29-51.

BENJAMIN, Walter, Illumination, ed. Hannah Arendt, trans. Harry Zohn, New York, 1969.

BERNAUER, James, Explorations in the Faith and Thought of Hannah Arendt. Edited by James W. Bernauer, Boston/Dordrecht/ Lancaster: Martinus Nijhoff Publishers, 1987.

BILSKY, Leora Y., "When Actor and Spectator Meet in the Courtroom: Reflections on Hannah Arendt's Concept of Judgment." In Beiner, R. \& Nedelsky, J., (Eds.) Judgment, Imagination, and Politics - Themes from Kant and Arendt. New York: Rowman \& Littlefiled Publishers, INC., 2001.

BIRULÉS, F., "Poetica e politica. Hannah Arendt, Abitare il present," in La Politica tra Natalità e Mortalita - Hannah Arendt. Edited by Eugenia Parise, Napoli: Edizioni Scientifiche Italiane, 1993.

BULLO, Antonella, "Natalità, Mortalità e Memoria," In Hannah Arendt, introduzione e cura di Simona Forti, Millano: Bruno Mondadori, 1999.

CLARKE, James P., "A Kantian Theory of Political Judgment - Arendt and Lyotard." In Philosophy Today, Vol. 38, N. 1/4, (Summer 1994), 135-48.

COLLIN, Françoise, "Birth as Praxis," in "The Judge and the Spectator - Hannah Arendt's Political Philosophy, Joke j. Hermsen \& Dana R. Villa (Eds.) Leuven: Peeters, 1999.

DENNENY, Michael, "The Privilege of Ourselves: Hannah Arendt on Judgment." In Hannah Arendt: The Recovery of the Public World, edited by Melvyn A. Hill, New York: St. Martin's Press, 1979.

DINER, Dan, "On the Banal and the Evil in Her Holocaust Narrative." In New German Critique, N. 71, (Spring-Summer 1997): 177-190.

DINESEN, Isak, Daguerreotypes and Other Essays, Chicago: The University of Chicago Press, 1979.

DOSTAL, Robert, "Judging Human Action: Arendt's Appropriation of Kant," In The Review of Metaphysics, n. 134, 1984.

ERNST VOLLRATH, "Hannah Arendt and the Method of Political Thinking." In Social Research, Vol. 44, N. 1 (Spring 1977): 160-82.

FERRARA, Alessandro, "Judgment, identity and authenticity: a reconstruction of Hannah Arendt's interpretation of Kant." In Philosophy \& Social Criticism, 1998, v.24-2/3, p.110.

FORTI, Simona, "Sul 'Giudizio Riflettente' Kantiano: Arendt e Lyotard a Confronto." In $L a$ Politica tra Natalità e Mortalita à Hannah Arendt. Edited by Eugenia Parise. Napoli: Edizioni Scientifiche Italiane, 1993. 
FRIEDRICH Nietzsche, Ecce Homo, 'Thus spoke Zarathustra,'. In On the Genealogy of Morals, Ecce Homo. Translated by Walter Kaufmann, New York: Vintage Books, 1989.

GIUSTI, Roberto, Antropologia della Libertà - A comunità delle singolarità in Hannah Arendt, Assisi: Cittadella Editrice, 1999.

GRAY, J. Glenn, “The Winds of Thought," In Social Research. New York, (Spring 1977) Vol. 44: 40-62.

HAMMER, Dean C., "Incommensurable Phrases and Narrative Discourse - Lyotard and Arendt on the Possibility of Politics." In Philosophy Today, Vol. 41, N. 4/4, (Winter 1997), pp. 475-90.

HANS JONAS, “Acting, Knowing, Thinking: Gleanings from Hannah Arendt's Philosophical Work.” In Social Research. New York, 44/1 (Spring 1977): 25-43.

HELLER, Agnes, An Ethics of Personality, Oxford \& Cambridge: Blackwell, 1996.

YARBROUGH, Jean \& Stern, Peter. "Vita Activa and Vita Contemplativa: Reflections on Hannah Arendt's Political Thought in The Life of the Mind," in The Review of Politics, vol. 43, N. 3, (July 1981), pp. 323-54;

ESLIN, Jean-Claude, "L'Événement de Penser," in Esprit - Changer la culture et la politique,

“Hannah Arendt," N. 42, 2 édition, Juin, 1985, pp. 7-18.
KRISTEVA, Julia, Hannah Arendt - Life Is a Narrative. Translated by Frank Collins, Toronto/Buffalo/London: University of Toronto Press, 2001.

LEFORT, Claude, "Hannah Arendt and the Political," in Democracy and Political Theory, University of Minnesota Press: Minneapolis, 1989.

MÁRQUEZ, Gabriel García. Vivir para contarla. Barcelona: Mondadori, 2002, epigraph.

McCLURE, Kirstie, "The Odor of judgment: Exemplarity, Propriety, and Politics in the Company of Hannah Arendt." In Hannah Arendt and the Meaning of Politics. Edited by Calhoun, Craig \& McGowan, John, Minneapolis e London: University of Minneapolis Press, 1997.

PIRRO, Robert C., Hannah Arendt and the Politics of Tragedy. De Kalb: Northern Illinois University Press, 2001.

TAMINIAUX, Jacques, "Événement, Monde et Jugement," in Esprit - Changer la culture et la politique, "Hannah Arendt," N. 42, 2 édition, Juin, 1985, pp. 135-47.

TAMINIAUX, Jacques, "Time and the Inner Conflicts of the Mind," In Hermsen, Joke, \& Villa, Dana, (Eds.) The Judge and the SpectatorHannah Arendt's Political Philosophy. Leuven: Peeters, 1999.

TASSIN, Étienne, Le Trésor Perdu, - Hannah Arendt, L'Intelligence de L'Action Politique. Paris: Éditions Payot \& Rivages, 1999. 